\title{
The Royal Household (Rajlok*) of Kachhawa Kings of Jaipur.
}

\author{
Manisha Choudhary \\ Assistant Professor Department of History Bharati College University of Delhi, India
}

\begin{abstract}
The aim of this paper is to explore the history of the Rajput rulers of Jaipur through the entry point of its Rajlok. The term Rajlok literally means the space inhabited by large number of queens, concubines, mistresses, patar, other inmates like baiji (princesses) and kawar (prince). Clearly, it was a site of restricted sexuality but excessive filial relationships. The status of ladies was well defined in a hierarchical order. The mother queen i.e. Majee Sahib genially controlled the happenings within the Rajlok. The power of majee sahib was not only confined to the domestic arenas it even extended in to the court and influenced the political shifts. Marriage alliances were forged for political and territorial gains. The queens were identified by their clan names not their personal names. Frequent visits of members from natal family to rajlok were striking feature. The nexus of rajlok not only influenced the marriage alliances with important rajput dynasties but also helped in carving political ambitions. Their chiefs (thikanedars) did same with non-kachhwah clans. The rajlok was also a site for king (Shree jee, huzur, maharajadhiraj) to welcome and bestow honor to the thikanedars. Whenever the mothers, wives, sisters and daughters of prominent thikanedar visited rajlok they were presented with gifts and money. On various festivals like teej, rakhi, diwali, dusshera and holi these ladies visited the rajlok. On many occasions ladies of chiefs were also invited. Clearly, relationships between royalty and families of chieftains were cemented through exchange of gifts and presents and by honoring them. The extended rituals performed in court and rajlok depict the hierarchy of thikanas. Thus, these religious happenings and festivals had connotation of political rituals.
\end{abstract}

Keywords: Padhravan, Rajlok, Sukh Niwas, Seekh, Thikanedars, Zenani Deodhi.

\section{Introduction}

In the last few decades scholars have shifted their attention from social and economic history to a wide range of themes like court culture, palace politics and gender issues. The eighteenth century which was earlier no men's field has been studied more closely. The weakening of the Mughals centre paved way for the emergence of various regional states all over the country. The Amber/Jaipur state which was a close associate of the Mughals during the sixteenth and seventeenth century gradually distanced itself from the empire. During the eighteenth century in the absence of Mughal legitimating authority the Jaipur state leaned on alternative sources of its legitimation. The state of Jaipur developed a mechanism of seeking legitimacy from the religious and political dignitaries who were located in and around Jaipur. The state received various mahants, purohits, fakirs and political dignitaries (thikanedars) who were important for the state. The ceremonies associated with the reception, padhravan (welcome), seekh/ ruksadi (seeing off) and darbar dastur (court ritual) depict the political importance of these dignitaries. The centre for performing all these rituals was court and Rajlok. The court was a centre for all the business related to state whereas; the Rajlok was an excluded place where only those dignitaries who were crucial in state affairs were invited by the king. In this paper an attempt has been made to highlight the organisation and structures of power in the Jaipur state during $18^{\text {th }}$ century. The state of Jaipur constantly manufactured consent of various political and religious groups to prop up its power. ${ }^{1}$

Historians have made efforts to find out the links of the imperial household which affected the court politics. Some historians have studied the royal household and understand its inner politics related to succession and acquisition of power. The Mughal household (harem) has been studied by many historians and they successfully brought out connection of the royal household with court politics, which in the long run affected the fortunes of the empire. ${ }^{2}$ Though the impact of the household politics on the larger politics of the Mughal Empire have been studied in detail there has been a relative negligence of the royal household politics of the post-Mughal and pre-colonial states. Hence, an effort has been made in this paper to examine the sources of the Kachhwaha household in order to explore its inner dynamics. The Rajlok of the Kachhawaha kings is equivalent of the Mughal Harem both of which literally mean the royal household. K.S. Lal's pioneer work on the household of the Mughals, is a detailed narrative of the functioning and organisation of the Mughal Harem. He

\footnotetext{
*Rajlok, literally means royal household. A document Dastur Komwar Rajlok is preserved in Jaipur Historical section of Rajasthan State Archives at Bikaner. It records the day to day functioning of the royal household.

${ }^{1}$ R.P Rana, "Chakar To Raja, The Emergence of Naruka State of Alwar (c.1660-1790)" Social Science Probings, june 2006, pp.59-79.

${ }^{2}$ Rekha Mishra, Women in Mughal India (1526-1748), Munshiram manoharlal, Delhi, 1967, Ruby lal, Domesticity and Power in the Early Mughal World, Cambridge University Press, New York, 2005.
} 
found the Mughal harem as a complete world which catered to all the needs of the Emperor. All the functions and rituals of the harem were centred around the Emperor. Harem for emperor was a place to seek pleasure. K.S.Lal's work provides a deep insight into its working. ${ }^{3}$

Harbans Mukhia in an interesting work tried to locate the various cultural functions, etiquettes and court culture of the Mughals. He studied the sources of the Mughal states legitimacy, the evolution of court etiquette and the world of the imperial mughal family. The extended etiquettes and mannerism associated with the mughal harem made it a place of decorum as well as pleasure and joy. ${ }^{4}$

Another significant work which reveals the political significance of harem is by Ruby Lal. She argues that the residents of domestic arenas influenced the various political shifts of Mughal India. Through her research, she is able to understand the influence exercised by the inmates of harem. For changing, controlling, shifting and managing powerful positions for self and their children the harem proved to be a vibrant space. Competition, hostilities and constant rivalries were common amongst the inmates of the harem. All the queens, concubines and inmates had their own retinue of servants (maid-servants), who were loyal and honest to their masters. Through these servants they hatched conspiracies and passed on messages. The inmates of harem not only hatched conspiracies for the power but even tried to gain benefits. At many occasions these women also declared their false pregnancies and tried to control the politics through re-production. Because, the status of any women in harem largely dependent on the birth of a male-child and heir. ${ }^{5}$

Clearly significant research has been carried out by historians to understand the dynamics of harem of the Mughals. Somehow the palace politics of regional kingdoms has been neglected so far. The Jaipur state was one of the regional kingdoms which became autonomous in the $18^{\text {th }}$ century. In the course of their association with the mughals the Jaipur rulers had become familiar with the mughal courtly culture. Jaipur state in $18^{\text {th }}$ century and $19^{\text {th }}$ century had much of the rituals, which were adopted from the Mughal court and empire. ${ }^{6}$ The elaborate rituals were not only in vogue in the Jaipur court but many rituals also impacted the royal household (Rajlok).

\section{The Royal Household:- Rajlok}

The royal household of Jaipur state was called Rajlok which literally means a space peopled by the members of royal family. The royal household (harem) of Mughals was a common space for all the ladies including the mother, queen, chief queen, wife, co-wives, inmates and concubines, but the hierarchy of ranks existed. Rajlok was an extensive structure with various concrete complexes. The hierarchy of rank existed amongst the ladies. The Rajlok included various complexes such as Sukh Niwas, Pritam Niwas, Chand Mahal, Sabha Niwas and Zenani Deodhi. The Sukh Niwas was the King's palace where he resided with the chief queen (pat rani). Pritam Niwas, Chand Mahal, Sabha Niwas were the complexes for receiving the dignitaries of state. The entries to these complexes were selective in nature depending on political status of the visitor. The restricted entries are suggestive of preferential treatment given by the Raja to various rulers of different states, thikanedars, purohits and mahants. Many of these dignitaries were seen off (vida) from Diwan-i-Aam. Zenani Deodhi (female apartments) was an extended complex where the mother queen (majee sahib), prince (chimnajee Ikuwar jee), princess (Bai /laad Kawri), queens (rani), concubines (pardaayat), inmates (paswans) and dancers (pattr) resided. There were separate apartments allotted to each lady according to her status. These separate apartments were called as rawalas (small palace). Thus, the Rajlok accommodated all the ladies related to the king in different capacities.

The Zenani Deodhi adjoining the city palace of Jaipur is fully a concrete structure with corridors, rooms, varandas, chowks, chattris, jharokhas, and rawlas. The architecture of the Zenani Deodhi kept the life of inmates quite secret. The inmates living in adjacent apartments lived completely ignorant of the happenings and life of other inmate. These concrete structures also kept the visits of king (to any of the lady) a secret in Zenani Deodhi. Long running corridors with doors at the end, were connected to the king's apartment. These doors were always kept closed and sealed for security purpose. These doors were only to be opened on the order of the King. ${ }^{7}$ The Zenani Deodhi was guarded round the clock by a retinue of loyal and trustworthy eunuchs called Nazir. The highly organised and heavily guarded structure of Zenani Deodhi kept the lives and happenings of these women secret and invisible.

Zenani Deodhi was an extensive and highly organised unit of palace where all the rituals, customs and ceremonies were conducted. All the festivals, king's birthday, marriages, child birth were celebrated by all the members of Rajlok with pomp and show. The festivities and celebrations inside Rajlok kept the inmates occupied. Besides it the Rajlok was also a centre for various political and religious rituals. The functions of

\footnotetext{
${ }^{3}$ K.S.Lal, The Mughal Harem, Aditya Prakashan, New Delhi, 1988.

${ }^{4}$ Harbans Mukhia, the Mughals of India, Blackwell Publishing, USA, reprint 2005.

${ }^{5}$ Ruby lal, Domesticity and Power in the Early Mughal World, Cambridge University Press, New York, 2005.

${ }^{6}$ Ramdev p. Kathuria, Life in the Courts of Rajasthan, during the $18^{\text {th }}$ Century, S.Chand \& Company Ltd., New Delhi, 1987, pp. $300-322$.

${ }^{7}$ Varsha Joshi, Polygamy and Purdah, Rawat Publications, Jaipur, 1995, pp.175-77. Here after Polygamy and Purdah.
} 
political and religious importance were all celebrated in different and unique ways. Rajlok was also a centre for making and re-emphasising political alliances through rituals, exchange of gifts and bestowing of grants.

The layout of Zenani Deodhi is marked by large number of corridors each leading to a separate apartment. The corridors are inclined planes, some of which lead into basement and some will take us to the first and second floor of the building. The corridors are designed by using the principals of geometry, where the person in basement can see the movements of corridors, but a view into the room from the corridor is not possible. The view of each apartment is blocked with number of small walls called pardi. ${ }^{8}$ Each apartment was inclusive of a living room extended with varamdas, a chowk, chattris and jharokas. These chowks were mainly used for celebrations and playing games. The chatrris were stages for playing board games like chess, chauser and hosting wine-drinking parties.

The living space of Majee Sahib in Zenani Deodhi was different in lay out as compared to those of other ladies. It included a big living room, along with two small chambers, one pillared varanda and a small room for worship. This structure was specially designed for consulting her on political matters. The individual apartments of other women were called as rawla. The rawlas are medium size rooms with an adjacent small room. These rawals had all the accessories and items required by the inmates. The items were provided by the state keeping in mind all the comforts of these ladies. The expenditure of all the requirements was incurred by state. ${ }^{9}$ The Zenani Deordi is a complex architectural structure. The rooms are constructed in rectangular shape, with a square shape chowk in the centre, which was a hub of festive celebrations.

The Rajlok was not meant only for populating the women associates of the king. Rajlok was also a centre for displaying the grandeur of the Kachhwaha kingdom and making political alliances with the thikanas (chiefdoms) who were received in the Rajlok and honoured. Throughout the year large numbers of occasions and festivals were celebrated and the thikanadars and their families were invited which helped in cementing the relations between the king and his chiefs. The occasions on which the thikanadars visited the Rajlok were not fixed. The thikanadars visited Rajlok only when the king invited them. The king married a large number of the women. These marriages provided an appropriate solution to political necessities. As the territories of the Rajput states kept on extending and contracting the marriages enabled any ruler or chief to renegotiate power with the others. Norman p. Ziegler aptly says "when Rajputs of different clans and gotras were involved, they usually confirmed settlement of such hostilities through the gifts of daughters in marriages and the formation of alliances (sagai) thus creating a new pattern of relationship among themselves. ${ }^{10}$ Even after marriage the ties of women (with their natal clans) continued to be strong that they were referred by their clan names such as Rani Shree Rathornejee ${ }^{11}$ Rani Bhattiyani ${ }^{12}$ etc. Both of them belonged to the Rathore and Bhatti clans respectively.

Since the Rajputs rulers strictly believed in clan exogamy they took wives from all the other important clans. In Rajasthan the leading rajputs clans were the Rathores, Sisodiyas, Kachhwahas, Hadas, Chauhans, Bhattis, Solankis, Jhalas, Jadams and Panwars etc.

The women married to a king can be divided into two groups. The primary group consisted of the Ranis, and in the secondary groups the Pardayats and Paswans can be included. The difference among the status of these women exited on the basis of the formal ceremony of marriage. The formal ceremony of marriage was not performed with the women of the secondary group though they were maintained as wives. The women of Rajlok can be divided in three broad groups. The first group included the Rajmatas, Majee Sahib, Ranijee, and Patranis. The second category included concubines' i.e, Pardayats and Paswans and Patars. The third category was formed by the other relatives of the ruler i.e Baijee, Kawaris and Davris.

In the order of precedence, Maajee Sahib occupied the highest and senior most position followed by Rajmatas, being the mother of the king. The Rajput and Persian tradition both allowed the mother of the reigning king a more dominant authority. ${ }^{13}$

A large numbers of female attendants were attached to the Rajlok. They included the dhaimas (wet nurses), dholans (drummers), bamanis (priests), nayans (female Barber), darjans (female tailors), Varis (cooks), and davris (female maid servants brought as dowry). Besides, this each rani had a separate retinue of servants to organise day to day affairs of her own establishment. The retinue of each queen was known after her like the servants of Rathore queen were known as Rathorniji ki sarkar. ${ }^{14}$ The chief of the female staff was called Badaran.

\footnotetext{
${ }^{8}$ A small wall of nearly 10-12 inches thickness and of 6-7 feet high.

${ }^{9}$ There are numerous instance in the registers no. 24 \& 25 of Dastur Komwar Rajlok where the requirements of the items like parda (curtain), Raas (plates), tharma (woolen cloth) and chikado (a toy for children) etc.were fulfilled from the various karkhanas (workshops) of Jaipur state. The karkahnas were mistri-khana, kirkiri-kahna etc.

${ }^{10}$ N.P. Ziegler “ Some Notes On Rajput Loyalities During The Mughal Period” in J.F.Richards(ed.) Kingship and Authority in South Asia, Madison, 1979, p. 232.

${ }_{11}^{11}$ Dastur Komwar-Rajlok, Register no 24 \& 25 p. 367. Here after DK-Rajlok

${ }^{12}$ Ibid. P. 257

${ }^{13}$ K.M.Ashraf, Life and Condition of the people of Hindustan, Oriental Publisher, New Delhi, 1970, p.55.

${ }^{14}$ Sobhas Singh Shekhawat, "Rajasthani ke Ranwaso ke Patra", Shodh Patrika, Octomber- December, 1979, p.73.
} 
Apart from individual staff members these were other servants in the royal household. Prominent among these was the darogha followed by his assistance. For the purpose of safety, security and administration of Zenani Deodhi, daroghas were appointed after consultation with the ruler. A large number of eunuchs known as Khojas were also employed, who strictly watched all the entrances and the communications of the Rajlok. They were also the medium of communication between king and the members of Zenani Deodhi. There is a colony called Mohalla Nadaran which lies just behind the Zenani Deodhi of the City Palace, which indicates to the houses occupied by the Nadars of Jaipur State. Today this colony is not consisting of any nadar but the name continues to be same. Anyone who wished to pay a visit in the Rajlok needed a prior permission from the palace. The males other than the king who could enter the Rajlok were purohits and rajkumars.

As stated earlier the concubines residing in the Zenani Deodhi were not formally married to the king, the suffix attached to their names suggest a clear hierarchy amongst them. The title of Pardayat was given to that women with whom the chura (bangle set) ceremony has been performed. It was not a formal marriage ceremony. The title of Paswan was bestowed upon the davris, dancer (patars), singers, and any other women for whom the king took fancy. All of these ladies inhabited in the Zenani Deodhi. ${ }^{15}$ Once the title of pardayats was conferred upon any woman then she was put in pardha, by giving them royal status. The wives of the ruler presented them gifts which were tokens of her formal acceptance. The ruler bestowed various titles to these pardayats, like rai, sukh (happiness), bai, chain, sahiba etc. ${ }^{16}$ Very few concubines received a number of titles like the pardayat of Raja Madho Singh, Pardayat sahiba shree Pholai rai and pardayat Kesar rai bai. ${ }^{17}$ The life of rani and pardayats was marked by extreme jealousy. Each one of them was competing for the favour and company of the ruler. In the words of Tod, "it is within the Rawala that intrigue is enthroned". ${ }^{18}$ Obviously, if polygamy solved some political problems of the Raja, it also generated lot of heat and tension in the royal household.

The Rajlok was a centre of various social and political functions. Invariably these functions and festivals kept the ranis and other inmates occupied. The occasions of celebration in the Rajlok were marriages and anniversaries, births and birthdays etc. Besides these occasions festivals such as Basant Panchami, Holi, Raksha Bandhan, Dusshera, Diwali, Gangor, Teej and Janmastmi were celebrated elaborately in the premises of female apartments. These festivals were also occasions for inviting and receiving guests from the important thikanas. ${ }^{19}$ As per the custom of clan exogamy the Jaipur king could not form a marriage alliance with any Kachhwaha offshoot. The king himself was a Rajawat. Besides this the Kachhwaha clan had proliferated into many branches. These branches are twelve in number they are known as Barakotris. ${ }^{20}$ There are various other off shoots of these kotris such as Rajawat, Naruka, Bankawat and Puranmalot. The dynasties with whom the Jaipur Raja formed marriage alliances were mainly Rathors, Bagels, Bhattis, Dhabai, Ranawats, Sisodiyas, Shaktawats, Bhanots, Hadas, Ranawats. ${ }^{21}$

The natal clans were always close and important to the woman who even after her marriage was known by her clan name, like Jadamijee, ${ }^{22}$ Rathornijee, ${ }^{23}$ Sisodani, ${ }^{24}$ and Bhatyyanijee ${ }^{25}$ etc. To uphold their family honour these queens rigidly followed the Rajput system of purda and sati. They were brought up in a manner where they would always think and act to save and protect honour of their clan. These ladies were well trained in reading, writing and wTeaponry. The status of the wives and concubines kept on rising and falling. All the elaborate rituals and functions were organised and arranged by the queens. The rituals of Rajlok were means for the fulfilment of various political ambitions through the observance of the festivals and celebrations. The most important occasion to receive and honour the daughters of thikanadars was Raksha Bandhan. ${ }^{26}$ There are various other occasions also when the daughters of thikandars were invited, received and presented gifts. In samvat 1781/1724 A.D. Bai Vichitar Kawar was granted thans of 3 gaz each from Kirkiri Khana on the occasion of rakhi which included 2 dupata of zari and 2 sarees of zari, ghagra of tas zari and 2 blouses. All these were sent at Palwal through Baghichand a helper of Ranawat jee. ${ }^{27}$ There are many instances like this in

\footnotetext{
${ }^{15}$ Varsha Joshi, Polygamy and Purdah, p.119.

${ }^{16}$ DK-Rajlok, pp.334-502

${ }^{17}$ Ibid., pp. 192, 415-431.

${ }^{18}$ James Tod, Annals and Antiquities of Rajasthan, Vol. I, p.246.

${ }^{19}$ DK-Rajlok, pp. 415-730. There are large number of festivals and occasions on which the guests are coming to Rajlok. Mainly on Dusharra and Raksha Bandhan.

${ }^{20}$ R.P. Rana, "A dominant class in upheaval: the zamindars of a North Indian region in the late seventeenth and early eighteenth centuries", The Indian Economic and Social History Review, 24,4, Sage, New Delhi,1987,p.404. the twelve kotris are Kilanot, Chatrbhujot, Nathawat, Balibhadrot, Khangarot, Sultanote, Panchanot, Gugawat, Kumbhani, Khumbhawat, Shivbhrampota and Banbirpota.

${ }^{21}$ DK-Rajlok, register no. $24 \& 25$. All the queens were known by their natal clan names which appear throughout the document.

${ }^{22}$ Ibid., P. 531.

${ }^{23}$ Ibid., pp.101, 367.

${ }^{24}$ Ibid., p.963-970.

${ }^{25}$ Ibid., p.849, 853 .

${ }^{26}$ ibid, pp. $415-733$.

${ }^{27}$ Ibid., p. 415.
} 
the Dastur Komwar which depict the importance of these occasions. If the daughter of some important thikanedar was unable to visit the Rajlok then gifts were sent to her through an important official.

As some thikanas became very powerful during the $18^{\text {th }}$ century, the state had to make and renew alliances with them. If the thikanadar is of the same clan then sending rakhi was the only means to keep the ties strong. In the $18^{\text {th }}$ century Jait Singh of Pahadnawala was constantly increasing his military strength for which the Jaipur state made a regular contact with him and every year his daughter was invited on the day of rakhi. ${ }^{28}$ Every year between 1718 and 1733 A.D Bai Laad Kawar daughter of Jait Singh Pahadnawala got rakhi. ${ }^{29}$ Every year she was given Rs. 40 as vida (seeing off) of rakhi. The other thikanas who were close associates of the king for long time were given separate and special treatment and their daughters were presented with money and gifts. In 1733 A.D Bai Laal Kawar, daughter of Guman Singh Kilanot got rakhi for the king she was received in the Rajlok and she was presented 57 thans from Kirkiri Khana. Along with it a sevgo of Rs. 47 and 2 anna, one sari of Rs 26 and 2 anna, a ghagra made of mashru with floral pattern (msahru butadar) of Rs. 14 and 1 anna, 1 blouse with floral designs made of zari costing Rs 7, 2 sevgos of Rs 9 and 2 anna of 6 thanas each, 2 sarees of print costing Rs 2 and 1 anna, 2 ghaghra of print costing Rs 1 and 3 paisa and 1 blouse coloured of 1 and $1 / 2$ metre. ${ }^{30}$ A section in Dastur Komwar- Rajlok contains information of the rakhi's received by the Jaipur Raja Sawai Jai Singh in 1734 A.D. On miti Fagun Budi 12 as per the rakhi's received the following were given of vida (seeing off) which amounted to a total of 25 mohars and Rs 2459 and 2 anna. ${ }^{31}$ In Samvat 1790/1733 A.D. in all18 mohars and Rs. 2420 and three annas were presented to the baijees who got rakhi for Shree jee (king).

The distribution of money and mohars is as follows ${ }^{32}$ :-

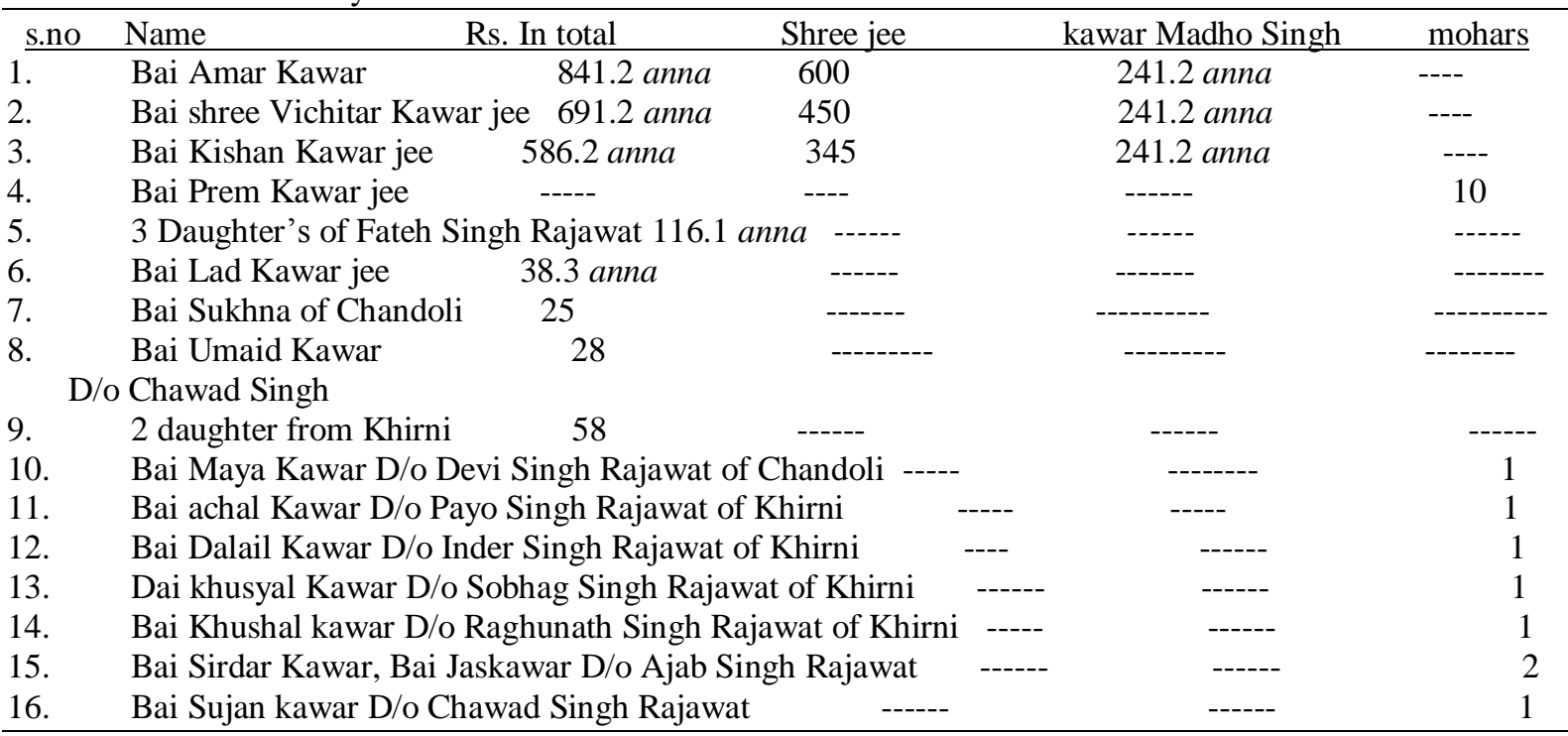

These elaborate gifts and presents suggest the political importance of these rituals performed in the Rajlok. All these festivals were closely watched by the King himself. The chief queen herself looked after the arrangements. Every year these Baijees (daughters) use to come for the festival of Raksha Bandhan and were honoured accordingly. In 1735 A.D. the number of mohars presented on the festival of Raksha Bandhan increased to 28 and the Rs came down to Rs $280 .{ }^{33}$

An interesting aspect of parda is visible in these documents where the names of bai's (daughters) are constantly appearing but the queens were referred by their clan names. The parda was applicable to the queens where their name was a secret to others. This might have been due to the popular culture and strict adherence to the purda which was applicable to the queens. The queens followed it to uphold the name of their clan.

The treatment given to the individual thikanedars and their female members in Rajlok depended upon the political significance of thikana. The thikanas with which only a formal relationship was maintained were treated differently and the value of gifts was also reduced. In 1788 A.D. on miti sawan sudi 15, Wednesday a

\footnotetext{
${ }^{28}$ Ibid., pp. $515-517$.

${ }^{29}$ Ibid., p. 515-518.

${ }^{30}$ Ibid., p. 518, in samvat 1790/1733A.D., on miti posh budi 6.

${ }^{31}$ Ibid., p. 708.

${ }^{32}$ Ibid., pp. 709-711.

${ }^{33}$ Ibid., p. 712.
} 
Rakhi was received from Dera Rampur of Purgana Chatsu, for which Rs. 5and one than of Mushra was presented and Rs. 1 was bestowed at time of seeing off $($ vida $) .{ }^{34}$

The festivals were not only the occasions for the exchange of gifts and bestowing honours. The other occasions for gift giving and bestowing siropao's were death ${ }^{35}$, condolence meetings $\left(\right.$ matami $^{36}{ }^{36}$, marriages ${ }^{37}$, and child birth ${ }^{38}$ and Bhai Duj. ${ }^{39}$

The highest position in Rajlok in term of receiving gifts and honours was of the Baijees. The daughter and sisters of the reigning king were always presented gifts of higher values in comparison to the daughter of the other Thikanas. In Samvat 1790/1733 when the sister of Madho Singh and daughters of Sawai Jai singh visited Rajlok on the occasion of Raksh Bandhan along with Baijees of the other thikanadars, they were given a large amount of money by king and the prince. ${ }^{40}$

Other occasions on which the mothers, wives, sister and daughters of the thikanadars visited the Rajlok were Diwali, Holi, Marriage ceremonies, Bhai Duj, Dusherra, Teej, Gangor and Sog (condolence). These are very few instances where the mothers and grandmothers of thikanadars visited king and the Rajlok. In 1766 A.D. the grandmother of Raja Hari Singh of Kama came along with her grandson to Jaipur, special arrangements were made for her stay at Badanpura. ${ }^{41}$

Many a times Rajlok also participated and made arrangement for marriage celebrations of the daughters of thikanadars. The Rajlok then acted as a centre for strengthening political alliances with the thikanadars and non-Kachhwaha other dynasties. For instance in 1769 A.D. the sagai ceremony of Bai Chandan Kawari (d/o Raja Hari singh jee Rajawat) was performed at Jaipur with Sisodan (s/o Maharaja Bhiv Singh ji Nathjee of Jodhpur). The arrangements for the ceremony of sagai were made in Zenani Deodhi of Majee Shree Chandowt jee. The male members who followed the bride-groom in Deodhi were Purohit Fateh Kishen of Madhu Sudan, Purohit Mansaram Kamdar of Majee shree Chandawatjee, Gulam singh; Naib of Zenani deodhi. The Majee sahib presented them 1 coconut, 2 gold mohars, supari and 5 units of mukara. ${ }^{42}$

Further the marriage expenses of Raja Hari Singh's daughter were borne by Majee Shree Chandawat jee from her own resources and Purohit Mansaram Kamdar was made incharge to look into the expenses individually. ${ }^{43}$ The jeeman (feast of marriage) was also arranged in Deodhi of Majee Shree Chandawat jee instead of darbar. ${ }^{44}$

These celebrations helped in reinventing and cementing the political alliances. The regularity of celebrations kept the relations intact. Special arrangements were made to receive any dignitary of importance. The entrance of Zenani Deodhi was highly guarded. The ladies apartments existed in complete exclusion. Sukh Niwas was the palace occupied by the Chief Queen. It was a heavily guarded palace. As it was residence of the queen, complete seclusion was maintained. But, there are few instances in the records which confirm that important guests of state were received and honoured in Sukh Niwas. In 1820 A.D. Nopal Singh s/o Bahadur Singh of Jhilai (an important Rajawat thikana) came to Jaipur from Bikaner. His formal admission into state service was accepted in the Sukh Niwas. He offered a nazar of Rs. 5 to Shree jee and Majee Sahib separately and gave Rs 4 of nichrawal (money which symbolizes warding off evil spirit). ${ }^{45}$

Raja Badan Singh of Bharatpur was a close associate of Sawai Jai Singh. In 1731 A.D. Bisham Singh S/o Badan Singh Jat and his wife visited Jaipur to meet Maharani jee Shree Rathor jee. For honouring the wife of Bisham Singh Jat valuable items given were:- 10 thans of 1 meter and 8 gaz each, 4 thans of 1 gaz each, 2 sarees of zari costing Rs. 34, 2 ghaghras of mashru butadar each of Rs. 12 anna and 3 paisa and Rs. 12 and 12 anna and 1 paisa, respectively. A blouse of 2 gaj made of zari costing Rs. 8 annas, one blouse of 2 gaj of print. ${ }^{46}$ Such a welcome extended to Badan Singh's family shows close ties between Bharatpur and Jaipur kingdoms.

Various other women from different dynasties and thikanas were also invited. Whenever, they paid visit a formal ceremony was organised in order to recognise and honour their presence. The functions and rituals, associated with jamana (birthday), janaiu parawan (ceremony of sacred thread), mundan (head shaving

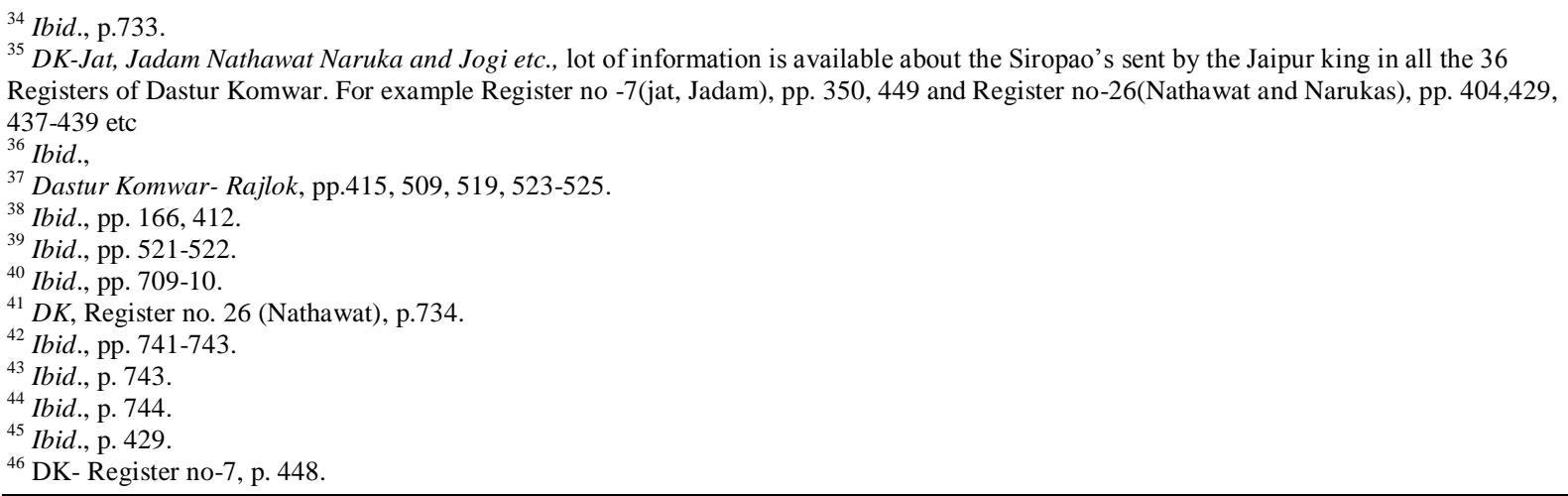


ceremony of child), chhati (sixth day celebration after child-birth) were also celebrated in the Rajlok. These functions reveal a clear hierarchy in the Rajlok. Here, Majee Sahib and Maharani jee had an upper hand over other women of Zenani Deodhi. On miti baisakh budi 2, Sunday the janaiu parawan of prince was done and on this occasion kawar jee was presented 71 mohars, and Rs. 50 and Rs. 100 were given for nichrawal. The guru mantra (a verse for recitation) was given by Bhatt jee Shree Govind Ramjee for granting of mantra he was presented 5 mohars and a threma pashmina butaadar (a shawl made of pashmina wool with floral pattern). The Gujarati guru bishabnath gaur jee presented janaiu so he was given Rupees-----. ${ }^{47}$ Though the purohits, gurus, mahants and the nazirs could enter the Rajlok but their movement was also limited. The gurus, mahants, and purohits were consulted by the queens and Majee Sahibs on various political and religious matters, and whenever they visited the Rajlok their area was marked beyond which they could never go. The nazirs were allowed free movement inside Zenani Deodhi as they were responsible for administration and organisation of Zenani Deodhi. The safety and security of Zenani Deodhi was also a responsibility of nazirs.

The pardayats and paswans were admitted into Zenani Deodhi after a formal ceremony of Chura Parawan (giving of bangles). The lives of these Pardayats and Paswans were also marked by large number of events and festivals throughout the year. The occasion of celebration for the pardayat and paswan were marriages of their children and the festivals like holi and dushera. In the marriage ceremonies of their children the pardayat looked after the arrangements themselves. The pardayats were not wedded wife, but were accepted after the chura ceremony, but once they were admitted into the Zenani Deodhi, they were provided all the facilities available to the queens. To get good husbands for their daughters the pardayats used their influence and exerted their authority to make the celebration of marriage a success. The pardayats also participated in all the celebrations arranged by the queens in the Rajlok. Specially, the marriages ${ }^{48}$, and child birth ${ }^{49}$ and festivals like Diwali, Dushara, Holi etc. At times they were formally invited. The condolence and funeral ceremonies were also the events where they presented themselves. ${ }^{50}$

Some of the pardayats became influential to the extent that the ceremonies associated with various functions were performed in their respective apartments. In 1889A.D. pardayat Pholi Rai became so powerful that her apartment was the centre for the celebration of the marriages. ${ }^{51}$ Around the same time during the reign of Sawai Ram Singh pardayat Bhurai Rai also acquired lot of influence. The power she exerted is indicated by the large number of gifts and items she received. The gifts presented to her included horse, elephant of mark (hathi nishhan $\mathrm{ka}$ ), horse with leash (ghoda lagam $\mathrm{ka}$ ), chandani (tent), sarpeach, kanat, lavajmo of zenani deodhi, palanquin and money etc. ${ }^{52}$

Bhurai Rai a paswan of Raja Ram Singh also acquired lot of wealth and power through her influences. By 1872 A.D. her influence rose to the level that while she was going to her natal family for the attending her brother's marriage she was presented with ceremonial gifts. A large number of the gifts and items were bestowed upon her which were specially meant for the queens. ${ }^{53}$

The Dastur Komwar shows a large number of pardayats, paswans and pattars living in Zenani Deodhi. The treatment given to the pardayats was better than that meted out to paswans and pattars (dancers). For instance pardayat Pholai Rai was called as pardayat Sahiba Pholai Rai jee. She was the only pardayat who was given grants and gifts for the celebration of her birthday ${ }^{54}$ and through her contacts she got her daughter Bai jee lal married to Inder singh s/o Rao Raja Tej Singh of Jodhpur. ${ }^{55}$ The reason for Pholai rai to attain such a status was the birth of a male child. In 1884 A.D. she gave birth to a male child. After the birth of this child she began to be addressed as pardayat jee sahiba shree pholai rai ${ }^{56}$ Before, it she was merely called pardayat pholai rai. ${ }^{57}$ On birth of the male child she was presented Rs. 8011 and the child Chimnaji (prince) was honoured with a gold bangles, 9 mohars and Rs. $341 .^{58}$ The birth of a male child in palaces was always desired and it also enhanced a woman's status. Mother of male child could become the chief queen and Majee Sahib respectively.

A large number of the pardayats were living in Zenani deorhi ${ }^{59}$ The title of pardayat was prefixed to their name like pardayat Jawahar rai ${ }^{60}$ pardayat Bhurai rai $\mathrm{ji}^{61}$, pardayat Mahtab rai jee ${ }^{62}$, pardayat Kesar rai jee ${ }^{63}$,

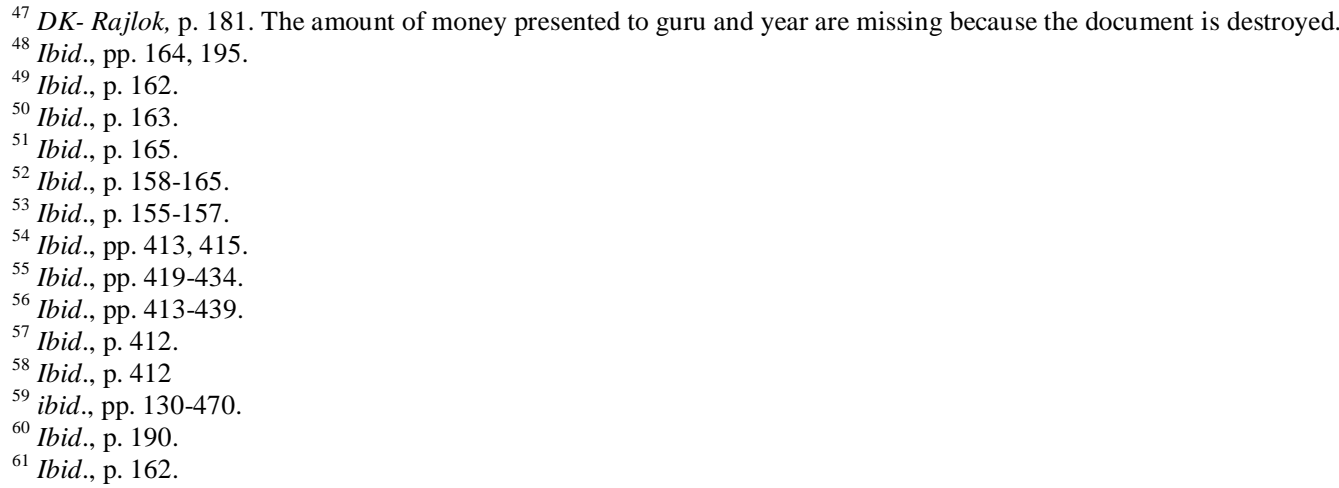


pardayat Manak rai jee ${ }^{64}$ etc. The paswans and patars were also given considerable importance as it is reflected in the records. The rituals associated with death were also strictly followed for Pardayats. In 1889 A.D. when pardayat Bhurai Rai died, all the rituals of funeral and crimination were followed. ${ }^{65}$ In 1914 A.D., pardayat Jawar Rai of Mewar died and the condolence feast called Baikuti was organised. ${ }^{66}$

Some pardayat enjoyed immense trust of the queens. It is reflected from the participation in the festivals and feasts where they were invited by queens. In Samvat 1953/1896 A.D., the Bai Jee Lal (younger dauther) of pardayat Keshar rai was married. The pre-marriage feast (banoro) of her was organised by Maharani jee Sahib Shree Jhalijee, Maharani jee Sahib Shree Chandawat jee and Maharani jee Sahib Shree Tawar jee together. ${ }^{67}$

The servants employed for taking care of the daily requirements of Zenani Deodhi were mainly from the families who were for generations dependent on the state for their livelihood. Many a times these servants rose to important position and exercised a lot of influence on the royal family members. One such case in Jaipur was of Rupa Badaran who became the virtual ruler of Jaipur for fifteen years. ${ }^{68}$ The davris (maid servants) rose to the status of Badaran. The Badarans were members of queen's personal staff whom she maintained for the day to day functioning of her Rawala.

The large numbers of eunuchs (khojas) were also employed by the state to guard the female apartments. In their official capacity they were known as nazirs. The eunuchs were well trained in the art of weaponry and communication skills. These eunuchs closely guarded and kept vigilance on the happenings all around the Rajlok. All entries to the Rajlok were scrutinized by Nazir and only after full satisfaction of quarries the entry was allowed. At times this important and respectable position allowed these Nazirs to acquire prominent positions in the state. A Nazir called Mohan Ram in 1818 A.D. got the nine year old son on the throne of Jaipur, with the title of Maharaja Sawai Man Singh. It was possible due to his influence on the Majees. ${ }^{69}$ Panna Miyan amd Mohan Nazir became very famous during the reign of Sawai Jai Singh and Jagat Singh respectively. Panna Miyan was so well versed in his work that Sawai Jai Singh orders him to engrave his name below Panna Miyan's name on the state seal. Then the nazir got "Ghulamast Panna, Badikosafi, Maharaj Agharaj Jai Singh Sawai" engraved on the state seal.

\section{Conclusion}

The paper focuses on the manipulations and complexes of the Jaipur household. Through the official connections the nobles tried to seek proximity to the king. The close association with the king was always rewarding for the Jaipur officials. The political relations of state were maintained from Darbar. For various state functions the Darbar was not only the arena. The Royal household of kachhwaha kings was also utilized to forge the political ties. The Rajlok was a centre where all the members of royal family lived together. But this space was never free of hostilities and jealousies. The defined hierarchies kept the relationships in a close knitted network of Rajlok. The princes were brought up under the guidance and care of Rajmata. While bringing up the prince the queens always triessd to exert their influence over him because that influence would ultimately help to determine their positions in the Rajlok. Beside the Rajmata, the other queens constantly made efforts to take charge of the necessities through which they can seek favour from the kawar. All the religious ceremonies and festivities observed in the Rajlok had clear political under tones. In the Rajlok some relationships limits of the norm and other failed to catch up with it. Unlike in the Mughal harem there are signs of understanding concubines in the Rajlok. However this point needs to be further propped up.

\section{Books:}

\section{Reference}

[1] Rekha Mishra, Women in Mughal India (1526-1748)( Munshiram manoharlal, Delhi, 1967)

[2] Ruby lal, Domesticity and Power in the Early Mughal World (Cambridge University Press, New York, 2005)

[3] K.S.Lal, The Mughal Harem (Aditya Prakashan, New Delhi, 1988)

[4] Harbans Mukhia, the Mughals of India (Blackwell Publishing, USA, reprint 2005)

[5] Ramdev p. Kathuria, Life in the Courts of Rajasthan, during the $18^{\text {th }}$ Century (S.Chand \& Company Ltd., New Delhi, 1987)

[6] Varsha Joshi, Polygamy and Purdah (Rawat Publications, Jaipur, 1995)

[7] K.M.Ashraf, Life and Condition of the people of Hindustan (Oriental Publisher, New Delhi, 1970)

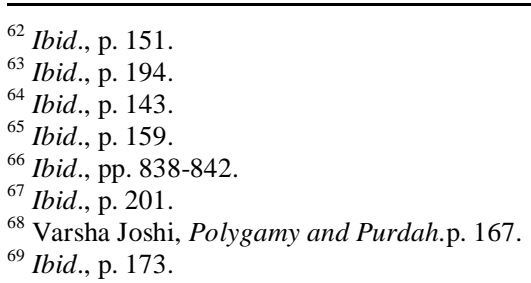

